\title{
Theory on the other Side of the Veil: Reckoning with Legacies of Anti-Blackness and Teaching in Social Theory
}

\author{
Angela Fillingim ${ }^{1}$ (D) Zawadi Rucks-Ahidiana $^{2}$ (D)
}

Accepted: 5 April 2021 / Published online: 17 April 2021

(c) The Author(s), under exclusive licence to Springer Science+Business Media, LLC, part of Springer Nature 2021

\begin{abstract}
Classical Theory courses in the U.S. present a history of our discipline grounded in the works of Durkheim, Marx, and Weber, defining "classic" by space and time, giving pre-World War II Europe credit for creating the foundation of contemporary sociology. While past critiques of this canon have argued for expanding the geographic bounds outside of Europe, these efforts still ground the origins of social theory in a time period of racial exclusion and segregation. We argue for a reckoning with the racial origins of the discipline in the United States in anti-Blackness and the legacies of racial exclusions. We must grapple with the histories of exclusion and segregation that continue to impact the discipline's present and futures. In this paper, we argue that the teaching of sociology's history should be through the "Foundations of Social Theory," a broad approach to teaching that rejects the ideas of both "classics" and a "canon." This approach roots theory in our history through core issues of study (e.g., the origins and consequences of capitalism) and directly addresses past racial and gendered exclusions by centering BIPOC intellectual contributions across time. By lifting the time and space restrictions, we open the doors to including voices omitted and repressed due to the exclusion of BIPOC people, especially Black women, from higher education in the U.S. This approach acknowledges the diverse histories and voices in our classrooms and profession, and highlights the relevance of social theory for our future.
\end{abstract}

Keywords Race $\cdot$ Social theory $\cdot$ History of sociology $\cdot$ Higher education

Angela Fillingim

fillina@wwu.edu

1 Fairhaven College, Western Washington University, Bellingham, WA, USA

2 Department of Sociology, University At Albany, State University of New York, Albany, NY, USA 
"The history of sociology is typically told as a history of its theorists and their theories."

(Lengermann and Niebrugge 2006, p. 2)

\section{Introduction}

With the murder of George Floyd, the increasing support for the Black Lives Matter movement, the violent attempted coup on the Capitol, and dramatic increases in anti-Asian hate crimes, the call to rectify racial injustices and address issues of race, racism, and white supremacy is not just a call to the country, but a call to our universities and the social sciences. That two of the officers implicated in Floyd's killing received undergraduate training in Sociology, has brought the need for a reckoning with race to our classrooms. Much like the rest of America, we must examine anti-blackness and white supremacy in Sociology, starting with acknowledging the role of both in the history of the discipline. In this paper, we address the need for a reckoning with the anti-Black origins of "Classical Sociological Theory" and the harm of centering racist, sexist, Euro-centric scholarship as the foundations of our discipline.

Reckoning with race is not only a response to the social circumstances we find ourselves in, but a much-needed response to the "moment of diversity" (Bonus, 2020) universities are currently in, as they reach new heights of racial and ethnic diversity among undergraduate students. Despite claims to promote diversity and inclusion, universities continue to offer educational programs that center white curriculum (Bonus, 2020). With the exception of Ethnic Studies ${ }^{1}$ and African American Studies, curriculum across universities, including the field of sociology, continues to de-center the perspectives of those representing the increasingly diverse student body including BIPOC, women, low-income, and first-generation college students.

While sociology is arguably most known for the study of inequality across the dimensions of race, class, and gender, the course that teaches the intellectual history of the discipline, Classical Sociological Theory, centers that history in the works of three white, European, cis-gender men. In fact, in our review of 34 syllabi, we found that Marx, Weber, and Durkheim are taught in over $90 \%$ of Classical Theory courses. Our dedication to the trinity (re)produces a temporal "geopolitics of knowledge" (Mignolo, 2005): We present the history of our discipline as grounded in Europe and tied to knowledge produced prior to World War II. Yet, Durkheim, Marx, and Weber were neither the founders of the discipline of sociology nor do their works address the ways in which race, racism, and white supremacy shaped the founding and development of the early U.S. In fact, their writings center Europe and whiteness, reinforcing a view of the world grounded in white supremacy and delineating sociology as a space for white thought. This project began in the 1970s

\footnotetext{
1 We include Indigenous Studies, Latinx/e Studies, Asian American and Diaspora Studies, and Critical Pacific Islander Studies under this umbrella.
} 
when BIPOC (Black, Indigenous, and People of Color) people were finally gaining full access to higher education. This temporal geopolitics of knowledge elevates whiteness as universal and marginalizes knowledge centering BIPOC perspectives as inferior, atheoretical, specific, and lacking rigor (Escobar, 2007; Grosfoguel \& Cervantes-Rodríguez, 2002; Mignolo, 2005; Quijano, 2007). Building Classic Theory around the works of Durkheim, Marx, and Weber presents their theories as universal, and, thus, relevant to budding American sociologists, but their Euro-centric, imperialist perspectives erases key social structures: anti-blackness and white supremacy. In the U.S. context, this specifically reinforces anti-blackness, pushing scholarship about and by Black people to specialized courses under the assumption that there are no universal, general theoretical concepts to gain from studies of the racially marginalized. In fact, Classic Theory has traditionally omitted even those Black scholars who did contribute to sociological thought prior to World War II through the definition of classic theory as emerging from Europe (Morris, 2015; Wright, 2012).

Instead of centering white curriculum as we teach undergraduate and graduate students about our intellectual history, and past and present concerns through courses on social theory, we must grapple with the fraught racial histories that shape sociology's pasts, presents, and futures. We offer this paper as a contribution to the ongoing conversations about sociological curriculum and pedagogy that acknowledges sociology's past and envisions its possible futures (Deegan, 1988; Morris, 2015; Wright, 2012; Itzigsohn \& Brown, 2020; Magubane, 2016; Go, 2013a, 2016, 2017). This paper serves as a pedagogical tool in the reckoning with race in teaching sociological theory, a way to acknowledge the whiteness in which sociology is rooted. While others have documented the ways that the "integration of the academy did not invite a transformation of thinking about social life" (Zuberi \& Bonilla-Silva, 2008, 16), we reflect on the ways that a "white logic," "a context in which white supremacy has defined the techniques and process of reasoning about social facts" (Zuberi \& Bonilla-Silva, 2008, 17) shapes a cornerstone of our discipline: Classic Social Theory courses. To do this, we focus on the structures that elevated the sociological trinity while also excluding BIPOC intellectuals ${ }^{2}$ from the "classics."

Our key claim is that we need to discard the idea of "classic," which ties the founding of our discipline to a specific time and place: Europe before World War II. We document how defining "Classic Sociology" by focusing on pre-World War II, European scholarly contributions centers the racist and sexist perspectives of the classics as the product of white men (see also: Connell, 1997; Go, 2013a, b). The sociological trinity was not inevitable, nor the only options presented for a canon, but the product of a purposeful construction of our history predicated on racial and gendered exclusions and, most importantly, anti-blackness (Connell, 1997; Deegan, 1988; Go, 2013a, b, 2016; Morris, 2015; Wright, 2012; Itzigsohn \& Brown, 2020; Magubane, 2016). In fact, exclusion and segregation by race and gender emerged in early American higher education and was replicated in the discipline of Sociology.

\footnotetext{
${ }^{2}$ We use intellectuals to recognize that because of racial-gendered exclusions, many BIPOC social theorists were excluded from the academe.
} 
Thus, a dedication to time and space limits "classic" theory by inherently excluding BIPOC scholars. Focusing only on pre-World War II, European sociology limits how we define "theory" (Abend, 2008) and teaches our students that only one kind of theory matters (Williams, 2018).

We offer as an alternative to the racist, sexist, and Euro-centric "Classic Sociology" teaching "Foundations of Social Theory." We use "foundations" to renvision the ways we teach the history of our discipline through theory and theorists. Given the racial and gendered exclusions we discuss below, the social construction and reproduction of "classics" is grounded in "white logics." Thus, "classics" embodies an exclusionary history and connotation. At best, keeping the term "classics" is indicative of expanding boundaries to include BIPOC scholars or other schools of thought (e.g., Connell, 2007; Go, 2016). Yet, this leaves intact the white logics and racial structures that have colored theory and continues to haunt us. Racism, or what Bonilla-Silva $(2003,13)$ defines as "the dominant racial ideology of the social system," structures our past and present. Thus, we use foundations to move toward transforming our discipline to reflect the social relations and the ongoing theorizations that have long existed in BIPOC communities; theorizations that have endured despite colonization, repression, and white supremacy.

To teach a history of sociology that honors the experiences of BIPOC communities, we propose grounding the Foundations of Social Theory in: (1) the historical context that produced the founding fathers myth; (2) BIPOC intellectuals' contributions to the core issues of study, and (3) the identities and experiences of our students. In doing so, we can continue to engage with the ideas of Durkheim, Marx, and Weber, but do so while centering BIPOC knowledge and acknowledging the racism, sexism, and Euro-centrism that contributed to the sociological trinity's work. We offer this paper as a tool to rethink our curriculum and pedagogy around the history of U.S. sociology including suggestions for how to teach the history of our discipline while centering BIPOC scholars. We focus on the U.S., which centers a specific history and racial hierarchy, but offer this as an example of the work that sociologists in other countries can do about their own hierarchies of difference. These conversations must honor the histories, intellectuals, and cultures that define each of our genealogies of sociology, rather than imposing a U.S.-centric vision on sociology globally. This paper thus serves as an example for approaching this work, not as a universal approach for revising sociological theory.

\section{Contesting Theory: Teaching about our Past and Future}

The content of "Classical Sociology" or "Classic Theory" has been the subject of much recent debate. Because theory is a means of professionalization, ${ }^{3}$ providing us with core concepts to understand social relations (Cuatro, 2013), these courses establish what Sociology is for our students, introducing them to the history of our

\footnotetext{
3 We use profession and discipline interchangeably throughout the paper, as not all who use sociology in their daily lives have access to become part of the professoriate.
} 
discipline and presumably the lines of thought that were foundational to defining our subfields of research. This course is so pivotal to the profession, it is required for most undergraduate and graduate Sociology programs in the U.S. It is because of the central role Classic Theory plays in defining the discipline that it has become the topic of debate as scholars challenge how our history is presented, whose narratives are centered, and whose are omitted (Deegan, 1988; Morris, 2015; Wright, 2012; Itzigsohn \& Brown, 2020; Magubane, 2016; Go, 2013a, 2016, 2017). We join this conversation with those calling for a more radical approach to revamp Classic Theory (Connell, 2007; Cuatro, 2013; Go, 2013a, 2016, 2020). More specifically, we argue for the need to redefine how we name and teach theory to redress the history of anti-blackness and sexism that marginalized BIPOC scholars and women in the academy.

The prior approaches to revise Classic Theory have largely fallen into two camps. The first has focused on specific scholars omitted due to the definition of Classic Theory as based in Europe. These proposals tend to focus on incorporating individual scholars such as Jane Addams or W.E.B. Du Bois, both of whom wrote and conducted research in the U.S. during the pre-World War II period (e.g., Deegan, 1988; Itzigsohn \& Brown, 2020; Lengermann \& Niebrugge, 2007; Morris, 2015; Romero, 2020; Wright, 2012). These individualist approaches center the U.S. social context and argue for incorporating the proposed scholar due to their methods, primary concerns (e.g., poverty, inequality), or relationship to elite institutions in the United States. Those centering the Settlement Tradition argue for the incorporation of Jane Addams and the scholars of the Hull House because they contributed to mainstream sociology through publications in such journals as the American Journal of Sociology, focused on social change, and provided an empirical and theoretical lens to urban social relations (Deegan, 1988). Located in Chicago between 1885 and 1930 (Romero, 2020), the Hull House scholars including Addams faced sexism and exclusion from a white-men dominated University of Chicago Sociology Department due to their focus on activism and practice (Calhoun, 2007; Deegan, 1988; Lengermann \& Niebrugge, 2007). Settlement associations like the Hull House provided women with funding and opportunity to study sociology in the settlement (Romero, 2020), opening the doors for predominantly upper-class, white women in higher education (Deegan, 1988; Lengermann \& Niebrugge, 2007). At the time, sociology departments did not grant women appointments, and instead women worked in the domestic sciences or home studies departments within the academy, or worked for government agencies to address poverty (Romero, 2020). Gender discrimination in higher education and in professional associations limited the role that white women could take in the professional field (Deegan, 1988). Yet, Settlement Sociology was also a tradition rooted in racist assumptions and white supremacy (Romero, 2020), as whiteness provided its members an opportunity for seeking "a new role in life and society" while leaving racial and class hierarchies intact (Deegan, 1988, 6). While Ida B. Wells did some work with the Hull House, Settlement Sociology largely centered white women, as seen in the face of the movement, Addams (Romero, 2020).

Experiences for Black scholars were profoundly more limited as seen in the experiences of another scholar subject to efforts of inclusion in the classic canon: W.E.B. Du Bois, whose intellectual journey also began pre-World War II 
(1868-1963), overlapping with Addams. Generally, scholars who advocate for adding $\mathrm{Du}$ Bois to the canon focus on his intellectual influence in the social sciences and highlight the ways that anti-blackness contributed to the marginalization of his scholarship (Morris, 2015; Wright, 2012; Itzigsohn \& Brown, 2020). Some also position $\mathrm{Du}$ Bois as the founder of particular traditions in the social sciences (Morris, 2015; Itzigsohn \& Brown, 2020; Battle-Baptiste \& Rusert, 2018; Vitalis, 2015). Wright (2012) and Morris (2015) detail the ways in which anti-blackness shaped Du Bois' career, confining him to segregated colleges, limiting his access to archives and resources for publishing. In fact, Du Bois was denied the opportunity to conduct a Carnegie study on race relations because the selection committee felt that Du Bois, as a Black person, was biased (Go, 2020). Empirically, Du Bois is argued as pioneering data visualization, and using quantitative data to assert, on a global stage, the humanity and accomplishments of Black people in the United States (Wright, 2012; Morris, 2015; Itzigsohn \& Brown, 2020; Battle-Baptiste \& Rusert, 2018). Du Bois thus played a central role in the origins and evolution of social science in the United States despite his exclusion from most institutions of higher education. The individualist approach brings central figures of U.S. Sociology into the classroom, but also still reinforces a notion of time that is inherently exclusionary, as the focus on pre-World War II is a period in which BIPOC people and women had limited access to higher education, especially Black women.

The second camp of scholars trace sociology's imperial entanglements and advocate for the transformation of the canon and for the inclusion of other traditions (Connell, 2007; Cuatro, 2013; Go, 2013a, 2016, 2020). A central theme of this work is recovering the role of empire or the global dynamics of white supremacy in shaping the scholarship of the Sociological Trinity and the formation of the discipline (Connell, 2007; Go, 2013b, 2017, 2020). This research cogently demonstrates that the presumed universal theories of the Sociological Trinity are in fact reflections of a social position (Go, 2016), and served to normalize imperial relations (Connell, 2007; Go, 2016, 2017). To remedy the shortcomings of Eurocentric perspectives, scholars look outside of the West to propose expanding the canon (Connell, 2007; Cuatro, 2013; Go, 2016, 2017, 2020) or to ground inquiry in themes rather than people (Go, 2013a). This work provides important social context for the Sociological Trinity arguing for an expansion of the spaces where theory can come from.

Thus, transformative approaches that center empire versus "Postcolonial Theory" focus on the economic, epistemic, ontological, and cultural legacies of empire (Go, 2016). We aim to advance these transformative approaches by outlining the histories of race, gender, and exclusion in the U.S. context, and offering paths toward transformation through how we (re)produce the history of our discipline in theory courses. As we detail below, this calls for an engagement with the structures that promoted the sociological trinity in the 1970s, and the legacies of exclusion that continue to haunt theory.

These two prior efforts both reject the notion that Classic Theory must be European in origins, but largely respect the bounds of time associated with the definition of "classic" (Deegan, 1988; Itzigsohn \& Brown, 2020; Lengermann \& Niebrugge, 2006, 2007; Morris, 2015; Romero, 2020; Wright, 2012). What we argue in this paper is that the problem with typical definitions of "Classic Sociology" are not just 
with the focus on place (Europe), but also with time (pre-World War II). Incorporating the perspectives of marginalized groups to Classic Sociology is impossible when restricting the period to a time of racial, gendered, and class exclusion from doctoral level education and faculty positions (Brewer, 2005; Evans, 2016). In other words, defining "classic" to pre-World War II inherently limits "classic" to those that had access to PhDs, largely white males (Brewer, 2005; Evans, 2016).

In this paper, we build on the prior transformative efforts to contest classic theory by accounting for intersecting racial and gendered structures that shaped the foundations of social theory in the U.S. We align ourselves with other calls to transform the way we conceive of theory (Connell, 2007; Cuatro, 2013; Go, 2016, 2017, 2020) and draw inspiration from the colonality perspective, a sociological and interdisciplinary paradigm rooted in the Americas (e.g., Grosfoguel \& Cervantes-Rodríguez, 2002; Mignolo, 2002; Quijano, 2007). This calls for an examination of the racial structures that elevated Durkheim, Marx and Weber and how Eurocentrism and erasure continues to haunt our past and present. These structures are predicated on the elevation of white-men in a context of anti-blackness, gendered exclusions, and the racialization of space. We must also seek out perspectives of BIPOC intellectuals that produced knowledge from subaltern epistemic and social positions. Per colonality, both are necessary to grapple with the history of our discipline and to understand the ways that race haunts our present. In teaching this means using multiple perspectives that travers time and space to name and dismantle social structures that perpetuate coloniality, or the persistence of the intersecting race, gender, and economic systems that perpetuate white supremacy. By centering the work of BIPOC intellectuals, we move away from the problematic idea of inclusion and toward a more liberatory approach of transformation.

\section{The Myth of European Origins: How Sociology Constructed "Classic"}

“...the Classical canon in sociology was created, mainly in the United States, as a part of an effort at reconstruction after the collapse of the first EuropeanAmerican project of sociology..." (Connell, 2007, p. 24)

The myth that Durkheim, Marx, and Weber established the discipline of Sociology solidified in the 1970s, producing a Classic Sociological Theory that centers the three as founding fathers that persists still today and restricts Classic Sociology to a specific time (pre-World War II) and place (Europe). To advance curricular and pedagogical changes, we must grapple with the historical context that shaped the rise of the sociological trinity. To re-envision the history and futures of our discipline, we must understand that the rise of Durkheim, Marx, and Weber was not inevitable, but the product of a social milieu. Thus, in this section, we document the dominance of Durkheim, Marx, and Weber in the current teaching of Classic Theory and briefly outline the construction of the sociological trinity.

Sociologists often view Durkheim, Marx, and Weber as the canon and founding fathers of American sociology (Magubane, 2016). This is evident in our analysis of syllabi in our shared disciplinary repository, the American 
125

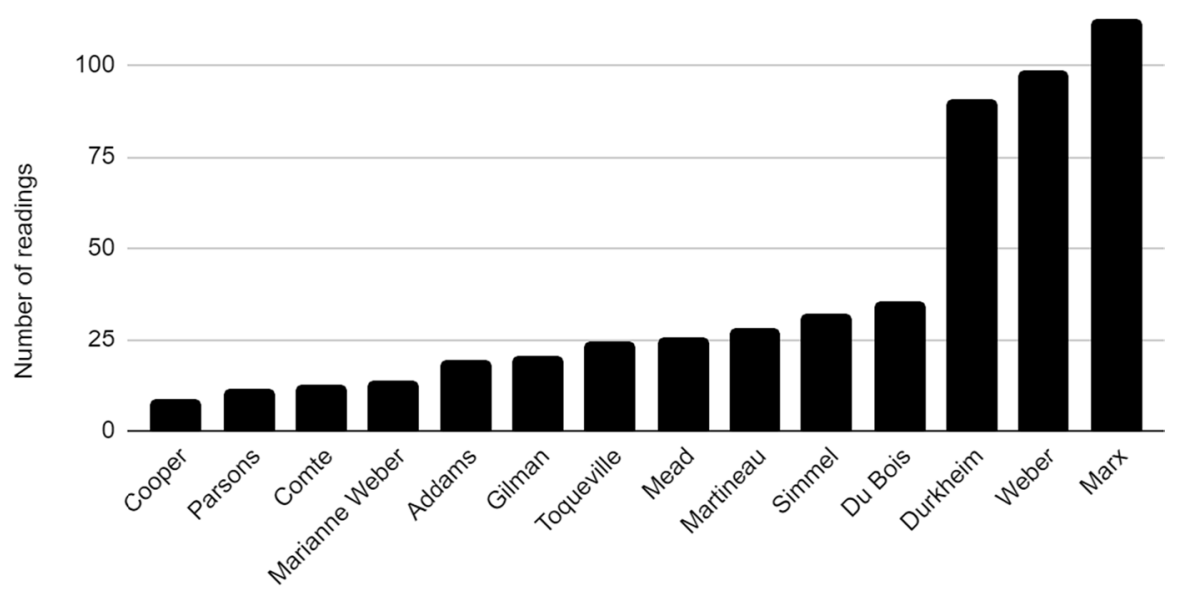

Fig. 1 Number of readings by theorist

Sociological Association's Teaching Resources and Innovations Library for Sociology (TRAILS). ${ }^{4}$ Across 34 syllabi for Classic Sociological Theory, the trinity appears in over 90 percent. $^{5}$ Furthermore, the works of Durkheim, Marx, and Weber had the most extensive engagement, as measured by number of readings. As shown in Fig. 1, of the 815 readings assigned across the 34 syllabi, 300 (37 percent) were readings by Durkheim, Marx, or Weber. The next most frequently assigned scholar, W.E.B. Du Bois, was only included on 16 syllabi (47 percent) including 35 readings across those 16 syllabi, despite his enormous corpus of research and writing. Durkheim, Marx, and Weber play a central role in how we currently engage with the history and theoretical foundations of our discipline both by measures of presence on Classic Sociology syllabi and by the amount of their work taught in those courses.

The works of these three scholars reflect a canon, which Connell $(2007,4)$ defines as "a privileged set of texts whose interpretation and reinterpretation define a field." 6 Our syllabi review demonstrates that Classic Theory instructors heavily favor the texts produced by the trinity. This centering of Durkheim, Marx, and Weber is due to the construction of the founding fathers myth, which credits the three scholars for establishing the discipline of Sociology and has produced a heavy reliance on the theoretical work of the three in sociological research.

The idea of the canon as rooted in the founding fathers was created and reinforced by the sociological community in the context of anti-blackness and racism of the

\footnotetext{
${ }^{4}$ Syllabi included on TRAILS (https://trails.asanet.org/) are voluntarily uploaded by course instructors to share with other members of ASA.

5 We excluded syllabi with course titles that contained "modern" and "contemporary" to focus on how we see the history of our discipline via the "Classics.".

${ }^{6}$ Given this definition of the canon, and how social theory is used to teach the history of our profession by revisiting key texts, we use canon and classic interchangeably in the remainder of the paper.
} 
1970s, a point we develop below. None of these European scholars trained in U.S. institutions nor contributed to building the departments of Sociology that emerged in American universities. In fact, none of these scholars were trained in Sociology as it was a burgeoning discipline that surfaced after their doctoral training. Focusing on Durkheim, Marx, and Weber in "Classic Sociology" centers a geographically and temporally bound history of our discipline, which overlooks the intellectual contributions of the scholars producing earlier American sociological work.

The founding fathers myth emerged in the 1970s, post-Civil Rights Movement (Connell, 2007; Go, 2020). During this period, whites resisted K-12 desegregation orders (C. Anderson, 2016; Delmont, 2016), limiting Blacks' access to education, particularly education supported by more resource allocations required for future access to higher education. At the same time, student movements agitated for Ethnic Studies departments and expanded access for communities of color in higher education (Ferguson, 2012; Okechukwu, 2019). In response, universities used a discourse of "excellence" to maintain the racial exclusions that defined higher education and to curtail the epistemic reorientation demanded by BIPOC students and aligned faculty (ibid.). The anointing of Durkheim, Marx, and Weber as the foundational history of our discipline must be read within a context in which "excellence" was used to reinscribe white logic. Said another way, excellence and the rise of the trinity should be read in light of the idea of "racial project" (Omi \& Winant, 1994), an epistemic project to affirm boundaries of the discipline that excluded Black scholars. The elevation of the trinity is part and parcel of the deliberate and ongoing exclusion of other voices and perspectives, and the epitome of a "possessive investment in white sociology" (Brunsma \& Padilla Wyse, 2019). Done at a time when BIPOC students were increasingly enrolling in higher education, the founding fathers myth defined whose views, contributions, and perspectives were deemed sociological and foundational to the discipline: dead European men invested in imperial projects.

Durkheim, Marx, and Weber were not the inevitable canon. In fact, the focus on the three eliminates the work of Hughes and Fitzhugh who first used the term "sociology" in English (Magubane, 2016), as well as the founders of the first U.S. Sociology departments: Giddings, Small, Sumner, and Ward (Breslau, 2007). Rather, the expansion of the discipline in the United States, translation of their works, and texts that cited their works, elevated the place of the trinity (Connell, 2007). With European universities suffering the financial and physical losses in the aftermath of World War II, American universities became the centers of intellectual development: "it was in the United States that sociology grew most dramatically and that the strongest traditions joining theory to empirical research were forged" (Calhoun, 2007, p. xi). Sociology flourished in this new environment as funding was directed to social reform projects that included addressing urbanization, immigration, crime, poverty, and the family (Calhoun, 2007, p. 2).

As Sociology departments grew in number, texts began to emerge to teach a narrative about the origins of the discipline. These early sociological texts credit Adam Smith, Condorcet, and Comte as founders, grounding the discipline of sociology in Europe where the university system was robust and flourishing prior to World War II and the first Sociology departments were established (Calhoun, 2007; Connell, 2007). The myth of the founding fathers came later with Talcott Parsons, Edward 
Shils, and their collaborators who centered European theory as the foundations of American sociology (Calhoun, 2007). Parsons' (1937) history of the discipline, subtitled "A Study in Social Theory with Special Reference to a Group of Recent European Writers," focused on Marshall, Pareto, Weber, and Durkheim (Connell, 2007). The myth was further reinforced with later texts such as Mills' influential work The Sociological Imagination (1959), which also referenced Durkheim, Marx, and Weber as central contributors to sociological theory. While Durkheim and Weber were integrated into the earlier narratives of the origins of sociology, Marx was predominantly added later as his texts influenced the rise of revolutionary movements in the 1960s both in the U.S. and abroad (Blomström \& Hettne, 1984; Connell, 2007). By the 1970s, Durkheim, Marx, and Weber were credited as the intellectual foundation of contemporary social theory as seen in Giddens' 1971 book Capitalism and Modern Social Theory: An Analysis of the Writings of Marx, Durkheim and Max Weber (Cuatro, 2013). With central figures of American sociology pointing to the importance of these three scholars and the growing availability of their texts thanks to their translation into English, Durkheim, Marx, and Weber were widely credited for the founding of sociology despite that the earliest scholar of the three, Durkheim, came late to the sociological debates of the time (Connell, 2007).

The centering of Europe as foundational to sociological theories had a strong influence on development theory, which allowed early U.S. Sociology programs access to government funding. As European centers rebuilt with aid from the U.S., the U.S. ascended to a position of world leader. Western nations faced a quagmire, as nations in Africa, Asia, and Latin America convulsed with challenges to imperial racial orders (Brostelmann, 2001; Krenn, 2006, 2012; Prashad, 2007). As the U.S. sought to manage these challenges to the world order, it recognized that economic inequality was a key issue. Yet, the question guiding policy was inherently racist: What is wrong with non-white societies (Krenn, 2006)? U.S. policies promoted economic and political "development" programs as solutions to unrest (Krenn, 2012; So, 1990). This context provided social scientists with an opening to expand their profiles by contributing to U.S. foreign policy efforts through the rise of development theory and benefit from funding to do so.

Development theory further cemented the role of the trinity. These paradigms drew heavily on the works of Durkheim, Marx, and Weber, which provided the social evolutionary foundations of major development paradigms (Blomström \& Hettne, 1984; So, 1990). Because of the centering of Europe and the basis of their works in imperial histories and archives, the founding fathers were easily grafted onto development paradigms. The founding fathers' works were rooted in the colonial assumptions of the deficiencies of non-white people, which was applied to "development" and modernization theory. Durkheim's view on structural functionalism was key to ideas of modernization, while Weber's views on culture and capitalism laid a foundation for work that linked cultural deficiencies to inequality. Third World movements, here we use the term in the sense of Prashad (2007) to talk about movements for dignity and self-determination, translated Marxist theories into their context and plan for liberation (Blomström \& Hettne, 1984). Thus, the international context also elevated the sociological trinity within intellectual circles and policy circles, centering Europe as the birthplace of social theory. 
The sociological founding fathers myth was the product of a broad landscape of social change in the 1970s: the American educational landscape expanding, the translation of key texts, the investment in early sociological research, the writings of central U.S. sociologists, and the exportation of U.S. sociology textbooks (see Connell, 2007). Key debates in development theory furthered the rise of the sociological trinity to canonical status by elevating the importance of their work to intellectual inquiry and public policy. This confluence of changes in funding, education, and universities gave rise to American sociology, grounded in the intellectual traditions of Europe as represented by Durkheim, Marx, and Weber. Thus although Durkheim and Marx were not widely accepted at the time that they wrote due to their Jewish heritage and anti-Semitism, they were elevated to the canon at a time when they were explicitly seen as white (see: Brodkin Sacks \& Brodkin, 1998, Jacobson, 1999) and thus used to center whiteness in response to the calls for universities to develop curriculum and departments that center BIPOC epistemologies, ontologies, and cosmologies.

The centering of Europe and perpetuation of the founding fathers myth continues even today as seen in the dominance of the three scholars among Classic Sociological Theory syllabi. This story of American sociology rooted in European imperialism omits important voices of non-white, non-cis-gendered men, devaluing the contributions of BIPOC and women scholars, particularly Black scholars.

\section{On the Other Side of the Veil: Race, Gender, and Educational Inequality}

"From the beginning of the founding of the first academic department at the University of Chicago, sociology has had a history of silencing voices that were different from the dominant white, male, bourgeois, and 'moral' voices of the founding "fathers"' (Peters, 1991, p. 248).

While transformation efforts to rethink the canon grounded in imperialism are important, we focus specifically on the U.S. to center what Blauner termed "internal colonialism," or the racial conditions that excluded and marginalized BIPOC scholars from ideas of classic theory within the United States. We avoid reproducing imperial dynamics that proclaim a singular vision of sociology, acknowledging that each country has its own historical hierarchies of oppression to grapple with. In the U.S., the dominant form of oppression is racism and anti-blackness, which we focus on in the context of classic theory and the early discipline of Sociology. We center the profound role of anti-blackness and the intersections of race and gender in shaping knowledge production including the systematic exclusion and segregation Black scholars faced in the academy and the long-term impacts of these practices. We aim to lift the veil (Du Bois \& Edwards, 2008) ${ }^{7}$ that hides BIPOC people from

\footnotetext{
7 The veil is the manifestation of the structural divide between the social worlds that whites and Blacks inhabit.
} 
white sociologists to include the scholarship of marginalized racial groups, particularly Blacks, on the other side. Thus, we build on Jung's $(2009,2019)$ point that it is intellectually important to grapple with the dual functions of white supremacy and anti-blackness in the construction of theory. When we engage with the underlying racial logics-white supremacy and anti-blackness in particular-we can reckon with the harm racism to BIPOC communities and the knowledge produced about and for these communities.

The emergence of the founding fathers myth came at a time when BIPOC people were finally gaining access to higher education outside of racially segregated schools due to the gains of the Civil Rights Movement. By tying the definition of "Classics" to a time in which only white men could easily get $\mathrm{PhDs}$, we reproduce racial and gendered limitations on what constitutes our discipline's intellectual history. White men, like the founding fathers and those that elevated them to the canon, were on one side of the veil with access to academia and $\mathrm{PhD}$ programs. On the other side of the veil, BIPOC people were broadly denied access to $\mathrm{PhD}$ programs. Furthermore, the few BIPOC people who gained access and completed $\mathrm{PhDs}$ were unable to publish their research in sociology journals and denied work as tenure-track faculty in predominantly white institutions. Our common definitions of "classics" inherently focus on a period in which racism, sexism, and classism defined the foundational scholarly work. Time (pre-World War II) and space (Europe) perspectives of the history of our discipline center the works of white, cis-gendered, upper-class men and remove their contributions from social contexts. In this section, we outline the systemic exclusions that shaped who was allowed to produce and disseminate knowledge, and whose knowledge was valued. Since others have detailed accounts of the exclusions of white women (e.g., Deegan, 1988; Lengermann \& Niebrugge, 2006; Romero, 2020), we look at the intersections of race and gender and center anti-blackness to highlight those who faced the longest exclusion from the ivory tower and broader knowledge production: BIPOC scholars, especially Black Women. Finally, we consider the implications of the segregationist and exclusionary origins of higher education for the emergence of American Sociology.

\section{The Exclusive and Segregated Origins of Higher Education}

The first American universities were founded on exclusion based on race, class, and gender (J. Anderson, 1993, 2002; Calhoun, 2007; Evans, 2016; Morris, 2015; Wright, 2012). These institutions were designed for upper-class, white, men in their pursuit of post-secondary education. When Black "universities" emerged in the mid-1850s, they were originally meant to serve students of all races, but whites refused to attend universities with Black students (Smith, 2016). Thus, they became what we now know as Historically Black Colleges and Universities (HBCUs), serving the broad educational needs of the Black community, which initially meant mainly focusing on high school level education and not providing any collegiate level work (Anderson, 2002; Wright II, 2002a, b). This racial division in higher education continued until the 1970s following the Civil Rights Act of 1964 and student activism pushing for opening the doors (J. Anderson, 2002; 
Bowen \& Bok, 1998; Ferguson, 2012; Hill Collins, 2007; Okihiro, 2016). Thus, the period when the canon was constructed was defined by deliberate practices of exclusion and segregation, particularly for Black women who were subjected to both racism and sexism in their pursuit of higher education (Crenshaw, 1990).

There were notable exceptions to patterns of exclusion. The early adopter of diversity in college admissions was arguably Oberlin College (J. Anderson, 2002; Bowen \& Bok, 1998; Evans, 2016; Smith, 2016). In 1835, the college opened their doors to men of color, and in 1837, admitted the first women (Bowen \& Bok, 1998; Evans, 2016). But the admission to and graduation of Black people from bachelor's programs, commonly called the "gentlemen's course" (Evans, 2016), was rare well into the early twentieth century (Evans, 2016; Matthew, 2016). By 1900, 2,541 bachelor's degrees had been awarded to Black people nationwide, including 252 Black women (Evans, 2016).

While Oberlin College continued to be at the forefront among white universities, HBCUs such as Fisk and Howard Universities were educating the vast majority of Black students (J. Anderson, 2002; Evans, 2016; Wright II, 2002a, b). The earliest HBCUs were founded in the mid-1850s in Pennsylvania (Lincoln University), Kentucky (Berea College), and Ohio (Wilberforce University), which was followed by more new schools after the Civil War (Wright II, 2002a, b). Most of these colleges were colleges in name only as they did not offer college-level coursework (J. Anderson, 2002; Wright II, 2002a, b). For instance, historical data shows that in 1916 "of the 7,513 students enrolled in the twenty-three African American public colleges, 4,061 or 54 percent were classified as elementary level students; 3,400 or 45 percent were considered secondary or high school level students; and the additional 74 were distributed between the categories of 'unclassified' and 'collegiate" (J. Anderson, 2002, p. 8). The segregationist and exclusionary policies in education meant that these lower levels of education were not readily available to Black Americans otherwise, so HBCUs stepped in to fill the void (J. Anderson, 2002; Wright II, 2002a, b).

Since completing a bachelor's was a prerequisite for acceptance into a doctoral program, very few Blacks even qualified to apply (Bowen \& Bok, 1998; Ferguson, 2012; Matthew, 2016). It was not until the courts forced southern states to provide equal educational opportunities with the Gaines decision in 1938 that Black K-12 institutions began to address the educational needs of Black Americans (J. Anderson, 2002). But even after the Gaines decision, access to education continued to be shaped by segregationist policies (J. Anderson, 2002).

As access to higher education slowly expanded, sexism continued to be a barrier for Black women. Black men gained access to elite white institutions of higher learning such as Harvard, Yale, and Stanford, while Black women continued to be limited to less prestigious colleges and HBCUs (Evans, 2016; Perkins, 2018). Du Bois himself was at the forefront of this product of male privilege, earning his $\mathrm{PhD}$ in History from Harvard in 1895 (Evans, 2016; Du Bois, 1940; Morris, 2015; Wright, 2012). In contrast, the first Black women PhDs came out of Radcliffe (English) and the University of Chicago (Germanic languages) in 1921 (Perkins, 2018). $\mathrm{PhDs}$ from Europe were more common for Black women, such as Anna Julia Cooper who received her doctorate in France in 1924. 
Despite these gains, Black Americans were largely limited to HBCUs until the 1970s (J. Anderson, 2002; Hill Collins, 2007). In fact, 80 percent of black college graduates in 1968 came from HBCUs (J. Anderson, 2002). Thus, most college-educated Blacks were limited to less prestigious universities, which in turn limited their access to doctoral programs. In part because of this it was not until 1941 that a predominately white institution awarded any Black PhD a permanent position in a tenure-track job, Dr. Allison Davis, a professor of Education at the University of Chicago (J. Anderson, 1993; Matthew, 2016). Even Du Bois was excluded from the privileged position of a professorship in a white college or university for the entirety of his lifetime despite his Harvard pedigree and extensive publication record (Morris, 2015; Du Bois, 1940; Wright, 2012). The structures of education included few Black PhDs and even fewer Black professors (Matthew, 2016).

Black scholars that did earn a PhD were limited to work in HBCUs, which predominately offered opportunities to Black men (J. Anderson, 1993; Morris, 2015). Du Bois only found tenure-track jobs at Wilberforce University and Atlanta University, both HBCUs (Morris, 2015). Similarly, his Black collaborators Monroe Work, Richard Wright Jr., and George Edmund Haynes, who include the first Blacks awarded PhDs in Sociology at University of Pennsylvania and Columbia University, only found tenure track employment at HBCUs until 1950 when Dr. Haynes became a Professor of Sociology at the City College of New York (Morris, 2015). Those Black scholars that worked at HBUCs had to manage budgetary constraints that demanded higher teaching loads, and provided little money for research support (Romero, 2020).

Since association with a prestigious university was often a prerequisite for acceptance by one's peers, the systematic exclusion of Blacks from the acclaimed centers of intellectual life also meant the systematic exclusion of them from the canon, particularly due to the segregation of Black PhDs in HBCUs (Morris, 2015; Vitalis, 2015; Wright, 2012). The discipline of sociology emerged under these conditions of racism, sexism, and elitism in the academy.

\section{The Emergence of American Sociology}

In this context, American sociology also emerged as exclusionary and segregated. The first sociology department was founded at University of Chicago in 1892 followed by Columbia University in 1893 (Calhoun, 2007). The expansion of Sociology departments was rapid in the U.S. By 1928, "there were 99 independent departments of sociology, plus 48 more that combined sociology with another social science" (Camic, 2007, p. 229). With more departments and more resources, the number of sociology doctorates steadily increased from 13 in 1920, to 26 in 1925, to 40 in 1930 (Camic, 2007). But these departments and doctoral programs reinforced the racist context of higher education in two ways. First, the early discipline built on biology, using Social Darwinism and eugenics to support the existing racist ideologies that Black people were inferior to Whites (Breslau, 2007; Calhoun, 2007; Morris, 2007, 2015; Winant, 2007). Second, in distinguishing the discipline, sociology silenced 
Black scholars, pushing their scholarship to the periphery, excluding them from tenure track positions, and omitting their contributions to the discipline (Breslau, 2007; Calhoun, 2007; Hill Collins, 2007; Lengermann \& Niebrugge, 2007; Morris, 2015; Peters, 1991; Wright II, 2002a, b). ${ }^{8}$

Early sociology relied on biological ideas of social evolution to explain social differences with Social Darwinism, such as the work of William Graham Sumner and Franklin H. Giddings (Breslau, 2007; Calhoun, 2007; Morris, 2015; Winant, 2007). American sociologists used biological ideas to support the commonly held assumptions that Black people were inferior to white people (Morris, 2007; Winant, 2007). "[W]hite social scientists concurred with the general white consensus that blacks were created inferior and incapable of functioning as social equals of whites" (Morris, 2015, p. 3). Even the sociologists who rejected the idea of biological differences, like Robert Park, supported the idea that Blacks were culturally inferior to Whites (Morris, 2007; Winant, 2007). Park thus focused on assimilation as "Black people needed to master white culture and demonstrate that they could measure up to the standards of European civilization" to be accepted in American society (Morris, 2007, p. 507). These racist ideologies were common in early sociological publications, as seen in the American Journal of Sociology's lead article of 1904, an introduction to the eugenics movement by Francis Galton entitled "Eugenics: Its Definition, Scope, and Aims" (Morris, 2015). American sociology thus reflected broader "racial scripts" (Molina, 2014) that presumed non-white people were inherently inferior.

In addition to reinforcing racist ideologies through theory and research, the early discipline purposefully excluded Black scholars by separating theoretical sociology from applied sociology, a practice that also had implications for white women (Breslau, 2007; Calhoun, 2007; Lengermann \& Niebrugge, 2006, 2007). To establish sociology as a legitimate discipline, early sociologists aimed to represent the discipline as akin to philosophy, bringing big theoretical ideas about how humans interact and create societies, and separating itself from the service-based profession that became Social Work (Breslau, 2007; Calhoun, 2007; Lengermann \& Niebrugge, 2007). Albion Small, the chair of the first sociology department in the U.S. at the University of Chicago, described this focus in a 1912 article in the American Journal of Sociology, reflecting discussions happening in the early years of the American Sociological Society (now known as the American Sociological Association) (Lengermann \& Niebrugge, 2007).

Like all sciences which embrace fundamental principles and concrete elaborations of the same, sociology falls naturally into two parts. General sociology is study of the conditions (physical and psychical), elements, forms, forces, processes, results (at given stages), and implications of human association. Special sociology ('applied sociology,' 'social technology,' 'Sozialpolitik') is procedure on the basis of a presupposed general sociology, particularly upon the presumption of certain ascertained social values and corresponding pur-

\footnotetext{
${ }^{8}$ Also see Yu (2001), Jung (2009), and Go (2020) for a review of anti-Asian expressions in early US sociology.
} 
poses, to work out feasible programs for social co-operation which will assure

progress toward attainment of the purposes (Small, 1912, p. 200).

The leaders of the discipline, who achieved their status in a context of racial exclusion, worked to preserve these exclusionary measures. They separated Sociology from Social Work (also referred to as Applied Sociology) using the distinction that Sociology was based on theory, thus drawing a bright boundary between sociology and the works of Black scholars like W.E.B. Du Bois and Ida B. Wells. In fact, Small explicitly excluded empirical work from sociology, defining sociology instead by the use and focus on formal theory, which Small argued social workers and scholars like Du Bois lacked (Lengermann \& Niebrugge, 2007). The distinction between theoretical sociology and applied preserved a white-men centered discipline by separating the works of Black scholars who not only conducted the first empirical sociological studies done in the U.S., but also used their research to advocate for the marginalized and oppressed (Lengermann \& Niebrugge, 2007; Morris, 2015; Wright II, 2002a, b). Efforts to exclude these approaches from "General Sociology" brightened boundaries at a time when Black scholars were entering higher education.

The distinction between theoretical and applied sociology not only resulted in the separation of applied sociology into the field of social work, but also relegated early Black scholars to social work departments rather than sociology if they were accepted in white institutions, or to non-tenure-track positions in sociology departments (Breslau, 2007; Calhoun, 2007). "Typical [sociology] graduate departments included a single professor of theoretical sociology and a number of part-time practical [or applied] sociologists...Programs that did not include graduate study were even more focused on training for practical work, and these were often the departmental home of university training in charity and social service work" (Breslau, 2007 , p. 59). This often relegated Black scholars to temporary positions such as lecturers or to HBCUs (Wright, 2012; Morris, 2015).

American sociology emerged in a fraught context. It came of age in an era of eugenics, Social Darwinism, and gender and racial exclusions. The systematic exclusion and the segregation of Black scholars to departments outside of sociology and non-academic research produced a discipline whose early scholars centered the perspectives, opinions, and interpretations of white, upper-class, cis-gender men (Hill Collins, 2007; Peters, 1991), which shaped the rise of the founding fathers myth. Anti-Blackness has continued to define educational systems in the United States, which has important consequences for what counts as theory and who is in the room to theorize. From white resistance to Brown v. Board of Education in the 1950s that led states to develop legal strategies to maintain segregation and deny funding to majority black schools to Reagan's reconfiguration of financial aid that led to an 8 percent drop in Black college enrollment including graduate programs (Anderson, 2016), education has been an important battle ground for the maintenance of white supremacy. The same structures of anti-blackness that limited access for early Black scholars persist today, limiting whose perspectives are privileged in the classroom and the questions and texts that demand "interpretation and reinterpretation" (Connell, 2007, 4). 
We continue to live with the legacies of anti-blackness in society and in the pipelines to our profession, which is most readily apparent in "epistemic inequalities" (Go, 2017) such as the relegation of theory to a particular time and space. The founding fathers myth emerged alongside efforts to restrict the discipline to white bourgeois men, making the anointing of Durkheim, Marx, and Weber, as the foundational history of our discipline a part of a "racial project" (Omi \& Winant, 1994) to affirm boundaries of the discipline that excluded Black scholars. Given the intersectional experiences of Black women, their contributions to sociology were even further limited by "epistemic inequalities." The elevation of the trinity is part and parcel of the deliberate and ongoing exclusion of other voices and perspectives, and the epitome of a "possessive investment in white sociology" (Brunsma \& Padilla Wyse, 2019), and furthermore, a white men's sociology. By contextualizing the sociological trinity in the racial and gendered contexts that define our discipline's history, we demonstrate that the canon was the product of the intersections of history, biography, and social structure, which we can use to train our students to consider the social construction of the canon. Our dedication to teaching the trinity as the history and present of our discipline through classic theory courses reproduces a "possessive investment in white sociology" (Brunsma \& Padilla Wyse, 2019).

\section{The Consequences of White Male Dominated Sociology for Teaching our History}

As noted in the epigraph for this article, we often tell the history of our discipline through social theorists. In teaching social theory, we must grapple with the social contexts of segregation and exclusion that define our past and present and be truthful about the contexts that gave rise to the trinity. Furthermore, we must make space for the voices historically (and contemporarily) marginalized in the discipline, particularly those that help us understand persistent social issues. While the founding fathers trinity has clearly influenced research and thus grounded our history in Durkheim, Marx, and Weber, we need to consider the implications of the explicit "racial projects" (Omi \& Winant, 1994) that elevated three white men as the trinity and marginalized BIPOC scholars. The task of a discipline rooted in white empire was to naturalize what Robinson (2007) terms racial regimes: systems that use race to justify social hierarchy, the subjugation of non-white people, and racial inequality, as seen in how the founding fathers myth elevates theorists that relied on biased imperial archives and projects (Connell, 2007; Go, 2013b; Steinmetz, 2013). This problem is especially important to address as our student body and professoriate are diversifying. Teaching and reproducing the founding fathers myth as our discipline's history reinforces that non-white scholars did not and do not contribure to our discipline, signaling to our growing number of BIPOC students that their voices and perspectives are not valued.

The founding fathers myth teaches a history of our discipline through the thoughts of white men and white empire, as opposed to empirical findings based on rigorous analyses. The work of the founding fathers privileges ideas of social evolution as the norm and universal. A common theme across their texts is that European 
society is the standard that all societies should strive to achieve. These theories are founded in imperial archives, collected through violent campaigns of conquest and colonization. When we remove these writers and writings from the contexts of empire and the racial aparthied in the U. S., we perpetuate imperial violence as normal and necessary to social evolution and progress, especially when we accept armchair theorizations as universal. We thus reproduce a dichotomy between "theory" and "empiricism" that was used to reinscribe a discipline grounded in white men and to reproduce racial and gender exclusions.

Yet the founding fathers myth also forces us to teach these problematic, Eurocentric works as the decades of dominance of the myth means that Durkheim, Marx, and Weber have had a large influence on the theoretical foundations of the discipline of Sociology. Instead of removing their works from our conception of Foundations of Social Theory, we argue that teaching about the works of Durkheim, Marx, and Weber must include an honest account of the ways that racism still haunts Sociology. Researchers in the U.S. reproduce the assumption of a racist research agenda based on empire, seeking to identify what was "wrong" with non-white populations or what made them "deficient" (Blomström \& Hettne, 1984; Connell, 2007; Ferguson, 2012; Okihiro, 2016). For instance, when Du Bois was tasked with studying the 7th ward in Philadelphia, the University of Pennsylvania wanted him to examine what was "wrong" with the Black population, a project that he refused. This perspective continues today with the normative judgement of BIPOC populations as seen in such recent works as Lawrence Mead's article "Poverty and Culture," which was withdrawn from publication due to racist assumptions and a lack of empirical evidence. We can see this question reproduced in studies that have led to major paradigms in the field, such as theories of assimilation, "the culture of poverty," and development theories. ${ }^{9}$ These paradigms are foundational to many subfields in the discipline and continue to shape contemporary lines of academic inquiry, including, for instance, efforts to revive the culture of poverty.

The reinforcement of the founding fathers myth also limits what theory "looks like" (Williams, 2018), which is especially important as our discipline continues to diversify. We present a history of our discipline and an image of theorists as white and men, reproducing racial and gendered biases and racial projects rooted in white supremacy. Said another way, we reproduce an epistemic myth that white men are the bearers of universal and objective knowledge and erase the racial and gendered structures that shape our past and present. Furthermore, we ostracize other forms of theory that are more empirically based (Abend, 2008). Thus, BIPOC scholarship, like Wells-Barnett (2012) study of lynching, are framed as examining a racial group's experience, rather than contributing to theory that defines the past and present of our discipline. In reality, her work, and the work of others, interrogates the intersections of history, society, and biography, while relying on empirical evidence to show how social structures are (re)produced.

\footnotetext{
${ }^{9}$ We purposefully omit citations for these racist works to not contribute to their standing in sociology with a citation count (Buggs et al., 2020).
} 
This dichotomy positions BIPOC scholars as "political," "advocates," "subjective," and simply "race scholars" (see also: Go, 2020).

Limiting what theory looks like has important consequences for our increasingly diverse student body. BIPOC and first-generation college students bring different histories and experiences with them into the classroom. Research shows that BIPOC students seek out knowledge that helps them interrogate the histories of imperialism and colonialism that define a collective experience (Bonus, 2020; Ferguson, 2012; Okihiro, 2016). They seek knowledge from the ivory tower to bring back to their communities (Bonus, 2020; Okihiro, 2016; Pérez Huber et al., 2018). The founding fathers myth is grounded in armchair theories that denigrate BIPOC people, history, and achievements, and limits what theory looks like. There is a clear symbolism to grounding our teaching in European sociology without a clear engagement with the racism that shaped these writings and how this haunts our past and present. We normalize imperial and colonial violence against Black, Indigenous, Brown, and poor bodies, reproducing the racial regimes articulated through and legitimized by the founding fathers' work. At best we obfuscate and at worst we naturalize systems of exclusion and the ways that "white rage" (C. Anderson, 2016) continues to shape our profession and society.

Rooting the history of U.S. sociology in European imperialism has important consequences at a time when our students are increasingly racially diverse. We normalize a history and disciplinary standard that reproduces racial and gender regimes, or heteropatriarchal white supremacy. As importantly, we limit what theory looks like to exclude the real variation in what constitutes "theory" (Abend, 2008). This limited focus ignores the history of the discipline, particularly by ostracizing the contributions of BIPOC scholars who faced racism, sexism, and classism that limited their ability to engage in academic knowledge production. This history of the discipline sends a clear signal to students of who we view as theorists and what literature we value as a contribution to the discipline. We reproduce the racism of the past by lowering our standards to include the armchair theories of the founding fathers while ignoring the empirical work of BIPOC men and women, thus reproducing the violence of imperialism by teaching the claims of white men as universal despite a lack of rigor and reliance on racist evidence. To prepare the next generations of our profession and our research, we must clearly address the imperial, racial, and gender exclusions that define sociology's pasts, presents, and futures. Even adding a few lone voices such as W.E.B. Du Bois or Jane Addams fails to live up to the promise of sociology by reinforcing exclusive parameters to definitions of classic theory. To be clear, we do not advocate throwing out the works of Durkheim, Marx, and Weber. Instead, we are critiquing teaching the founding fathers myth as gospel, without engaging with the contexts of race, gender, and social structure or giving any space to the perspectives of marginalized scholars. Given the racialized and gendered boundaries between applied sociology and theory, and the problems of archives (Trouillot, 1995), we must be open to texts beyond academic publications, beyond Europe, and across time. 


\section{Teaching the Foundations of Social Theory}

"Scholars who ignore the history of diversity in academia will remain poorly educated. This work shows that racial 'minorities' have long contributed much to higher education and that their increased access to academia should be based on that contribution." (Evans, 2016, p. 9)

To address the growing diversity of our discipline and our (unacknowledged) history, we must expand beyond the sociological trinity and beyond the constraints of space and time. While others propose a criteria to determine whether a person should be considered a sociologist (Deegan, 1988), we suggest a new approach to teach "Foundations of Sociology." This approach is grounded in: (1) the historical context that produced the founding fathers myth (as we modeled above); (2) BIPOC scholars contributions to core issues of study, and (3) the identities and experiences of our students. In the preceding section, we provide examples of how we can teach the context that produced the founding fathers myth.

To address the core issues of the discipline in ways that attempt to combat white logic, we must look both to BIPOC intellectuals and move beyond our idea of a canon rooted in specific texts. ${ }^{10}$ Given the persistent exclusion and marginalization of BIPOC scholars, we must seek out BIPOC texts inside and outside of academic settings. As Go (2020) points out, many BIPOC intellectuals engaging in sociology did so with a political urgency that applies to our current political conditions of persistent and growing racial inequality. Thinking of the canon as a set of texts that we revisit (see above) binds us to the racist epistemic structures that elevated the canon and that reproduces Marx, Weber, and Durkheim as gospel. Rather than canonize people or texts, we can root the history of our discipline in core concepts. This allows us to seek out works across time and space that will speak to an issue from different social positions, while allowing for intellectual freedom to reflect and revise our past and present in light of the diversification of the field and those that deploy sociology in their careers and political engagements.

This approach should center the identities of our students to better help them understand their lived experiences and inform their understanding of their communities and the world around them. There is ongoing urgency to relevancy. Sociology has important contributions to make to our understanding of pressing social issues, such as: the consequences of COVID-19 pandemic on racial and gender inequalities; the declaration of racism as a public health crisis, and persistent lethal violence leveled against communities of color. Thus, it is imperative that we marshall all of our resources to use the historic and present insights of our discipline to highlight the social forces that structure lived experiences and pathways toward liberation. We call this approach teaching "the Foundations of Social Theory."

This approach to teaching theory should be organized around core issues of study in the discipline (see also Cuatro, 2013; Go, 2020) and with consideration of the

\footnotetext{
${ }^{10}$ Given the persuasive nature of white logic, we do not proclaim to move beyond it, but rather, we are seeking paths toward liberation.
} 
strengths of one's department. This will require conversations and transformations at multiple curricular levels and potentially larger curricular changes. We might have to rethink our course readers and look widely for BIPOC work including open access sources. This is an opportunity to transform our discipline's past and present to embrace an explicit intentionality to center the works of BIPOC intellectuals across time. There is no one way to take this approach, thus we suggest a few different paths toward change. We recognize that this work can be difficult, especially for BIPOC teachers who may have to navigate departments invested in (re)producing a white centered sociology.

Teaching the Foundations of Social Theory around "core issues" allows a range of unique perspectives in theory courses under academic freedom and the variety of social contexts in which we teach. However, it must be accompanied by a deliberate effort to include the work of BIPOC scholars. This will naturally simulate debates. A vibrant part of our intellectual community is the range of views theorists hold of the field, which has produced exciting and productive debates in the literature. We believe the same kind of debate is necessary within departments, universities, and our national association. One productive path requires discussions and a reflection on what one's department has to offer. You might work with your fellow theory teachers to envision a BIPOC centered course that speaks to the key areas of study and teaching in one's department. Another may be discussing amongst faculty teaching theory the key ideas-social change, capitalism, social organization-that the course should explore. For instance, a course could focus on the origins, growth, and consequences of capitalism. Another reenvisioning could examine whether social change has been or is possible. Grounding conversations in core issues of study provides us with an intellectual opening to extend the discussion to a wider range of contributors to those debates.

By way of illustration, let us consider the proposal described above, which focused on the core issue of capitalism, and its origins, evolution, and consequences. The syllabus could use this piece to frame the course and introduce students to how our racist past haunts the present. Empirical works would begin by centering the work of BIPOC people, W.E.B. Du Bois' Black Reconstruction (1935), Ida B. Wells' twentieth century work on the causes of lynching (2012), Anna Julia Cooper's twentieth century writings on worth (2000), Cedric Robinson's Black Marxism (2005), and the theory of coloniality (e.g., Quijano \& Wallerstein, 1992). The course would then move to engage with works from Marx and Weber. This move both decenters whiteness but also allows us to grapple with the ways in which white supremacy shapes the works of the sociological trinity. This move also removes the universal assumptions of these works by centering experiences and perspectives outside of the scope of Durkheim, Marx, and Weber. The course could use the aforementioned works to examine: (1) what are the origins of contemporary capitalism; (2) what are the defining features of capitalism; (3) what are its consequences in people's everyday lives; and (4) what defines inequality within capitalist systems? In this way, we teach core issues of the discipline while allowing for a wider range of perspectives to help students construct the history and the debates that define sociology. At the same time, we disrupt a pedagogical practice of framing the white gaze as universal. Furthermore, this approach asks that students learn to view the world from 
different social positions and see the ways that history, society, and social position shape social analysis. Dr. Fillingim has found this to be a productive way to transform social theory into a space where BIPOC perspectives are a means to theorize social relations.

We imagine one question on our reader's minds:'Is there room for [fill in person's name or theoretical concept]?" Given the multiple levels of transformation that we outline above the answer is: that is up to you. But as you approach the process, resist the tendency to reinforce distinctions between "classic" and "contemporary" such as time restrictions that would reinforce excluding BIPOC scholars. Core issues of the discipline are not time delimited. For instance, one might wonder if we can teach Goffman's work on the presentation of self. The question that we believe is most important is, how can I (or "we" if this is a collective question) use a BIPOC centered approach to engage with the idea of the presentation of self? That might include Gonzales' (2020) look at how Black and Latinx women struggle with the presentation of self in activism using Women of Color Feminist and Queer perspectives, or Sims et al.'s (2019) study of how hair presentation affects racial perceptions by others. These works would lend themselves to a discussion of the ways in which race and gender shape our presentation of self, reinterpretation of self, and perception by others. These pieces could easily be put in dialogue with Goffman's ideas and theories. Starting with the work of BIPOC scholars has important epistemological and pedagogical consequences. We decenter whiteness, acknowledge the ways in which race shapes the presentation and interpretation of self, an undertheorized aspect of Goffman's work. Putting these works in dialogue highlights the presumption of white scholarship as ostensibly universal.

In addition to incorporating history, we must do the work to see our students' histories and life experiences and integrate them into our discussions of theory to help them better their understanding of the world around them. This includes seeking out theorists that represent different perspectives on core issues of the discipline. For instance, Dr. Fillingim, as a theory instructor at a university with students of Pacific Island origins, has sought out resources that highlight the place of Pacific Islander communities in the sociological theorizations of capitalism. As such, she teaches about the role of sociology in U.S. imperialism in the Pacific, and perspectives on how indigenous communities in the Pacific challenge imperialism and capitalism. Dr. Fillingim puts this in dialogue with Frantz Fanon's (1963) work on violence, and Ruby Ibarra's song "US," to examine the ways the consequences of imperialism and theories of liberation across time, space, and medium. These works highlight the global impacts of imperialism, as gendered interpretations of violence and liberation. This act simultaneously engages with core issues in the discipline (capitalism, social structure, social division, social change, gender) and key issues in students' lives, communities, and histories.

As we approach teaching the Foundations of Social Theory, we should also turn to other contemporary traditions. The rich and vibrant work of Black Feminist Theory, the Black Radical Tradition, Indigenous theorists, and Chicana/Latina theory can guide our thinking. We can look to BIPOC intellectuals to create a dialogue about key theories in the field across time and space. For instance, the question of liberation is a key issue that grounds various aspects of the discipline, from W.E.B. 
Du Bois' theorization of the "dark proletariat;" to Marx's views of class conflict; to Anna Julia Cooper's (2000) work on race, gender, and class; to Anzaldúa's (1999) theorization of gender, colonialism and sexuality; to Tuck's and Yang's (2012) theorizations of decolonization. A course can place these works in dialogue to understand the social structures that (re)produce oppression and different visions of liberation. Alternatively, a course could examine the intersections of agency, race, gender, and social structure, through the works of Wells-Barnett (2012) and Cooper (2000), James (2001) and Robinson (2005), Simpson (2014) and Calderon (2014), and Sandoval (2013) and Gonzales (2020). These works offer historical and contemporary insights into the discipline's long history of intersectional analysis. As a final example, a course could analyze the question of power from the perspectives of Cooper (2017), Fanon (1963), Rivera Cusicanqui (2012), alongside white European men theorists.

We offer these suggestions to begin the conversation of how we can reconcile the history of our discipline with the realities of race in the U.S. This kind of reimagining of a cornerstone of the discipline will undoubtedly be difficult and uneven. Changes may be incremental, as Dr. Fillingim has found in the way she revised her Social Theory course. There is an urgency to addressing the needs of our students, and our obligation to teach truthfully (Connell, 2019). While some might focus on the idea of losing a cornerstone of sociology, we argue that there is much to be gained by expanding how we think about social theory, who can theorize, and by centering the knowledges of BIPOC communities. While our approach is a U.S. perspective for reasons outlined above, the same approach can and should be applied to teaching theory outside of the U.S. by interrogating the histories of the core dimensions of inequality and centering the works of marginalized groups.

\section{Conclusion}

With the growing racial and class diversity in college students and the growing calls for racial justice, there is a particular urgency to reviewing the history of sociology and the way we represent and teach our origins. By describing sociology's origins through theorists (Lengermann \& Niebrugge, 2006) and the founding fathers myth, we frame Durkheim, Marx, and Weber as the canon and root our disciplines history in a time, pre-World War II, and space, imperialist Europe. This approach naturalizes a canon rooted in biased imperial archives and normalizes the omission and silencing of BIPOC scholars. Replicating and reinforcing this foundation has consequences for both the production and consumption of knowledge in our discipline: We reproduce a history of our discipline that refuses to interrogate the racial, imperial, and sexist structures that allowed the founding fathers to become the canon.

In this paper, we argue for moving beyond redefine "classic" to remove the space and time constraints used to justify and reinforce the founding fathers myth, while embracing the origins of the discipline as an empirical social science engaged with social justice (Feagin, 2001; Romero, 2020). To move towards a sociologically grounded history of the discipline in the U.S., we must grapple with the imperial, racial, gendered, and geographic practices that elevated white men and that 
deliberately excluded and marginalized BIPOC scholars to reckon with race. In this paper, we propose an approach to classic sociology that reflects the ways racism and sexism structure our past and haunt our present. We name this approach the "Foundations of Social Theory." This change is more than just semantic or symbolic. We believe it offers an intellectual flexibility to move away from the confines of the founding fathers myth and toward a more inclusive and historically grounded vision of the canon. This shift acknowledges the multifaceted ways that we can teach our discipline's history through theory. Further, this moves away from canonizing texts toward a reflexive engagement with what constitutes the core of our discipline by grounding our history in core questions.

Rather than focusing solely on Durkheim, Marx, and Weber, or even simply adding Du Bois or Addams to the canon, the Foundations of Social Theory approach is grounded in (1) the historical context that produced the founding fathers myth; (2) BIPOC scholars contributions to the core issues of study, and (3) the identities and experiences of our students. The approach allows for continued academic freedom and diverse pedagogies, while incorporating previously omitted voices of BIPOC scholars who were foundational to American sociology. While we focus here on American Sociology, this approach allows for the inclusion of global perspectives to understand key issues that define our past and present, as U.S. history has not transpired without other nations. Our task is to re-envision narratives of U.S.-based sociology, but also hope our work spurs a similar conversation for other regions and nations that have their own unique histories of oppression and disciplinary contexts to incorporate in teaching the origins of sociology and sociological theory.

While it may be tempting to rectify epistemological inequalities through a "Contemporary Social Theory" course, either as a requirement or option. This approach reproduces racial and gendered inequalities much like the advent of "applied sociology" or "Social Work" (see above). That is, by leaving the Durkheim, Marx, Weber trinity untouched and as students first exposure to sociological theory, we reproduce white racial logics of the discipline as sociological common sense, and ignore the enduring role of racism in the creation of our past and its reverberations into the present.

As we wrote this piece, the United States capitol was attacked by white terrorists, while Latin American people are being caged, Asian women were gunned down by a white supremacist, and Black lives continued to face systematic violence and systemic racism. There are important and powerful social theories that we can bring to understand the historical origins of these events, their consequences, and avenues for social change. As Connell $(2019,26)$ powerfully points out "movements for change need knowledge, explanations, strategic ideas and accurate information," thus, there is an important role that social theory can play in these struggles.

This shift will take time, but it is necessary. Our increasingly diverse students deserve the truth about the origins of modern-day sociology. They deserve to see themselves in the development of the discipline as the study of Black and poor communities was central to the foundation of American sociology. While BIPOC scholars are working to highlight the historic and present intellectual contributions of such scholars as W.E.B. Du Bois, Ida B. Wells, A.G. Dill, Patricia Hill Collins, Kimberle Crenshaw, and William Julius Wilson, making change requires a broader 
movement within the discipline. Much like the founding fathers myth was produced during "a second crisis in imperialism," as Connell (2007) argues, the present crisis in race relations offers an opportunity to appraise the history and future of our discipline in ways that are both inclusive and reflect the realities of history. Our aim is to spark conversation, reflection, and a movement to a future in which sociology can embrace its diverse pasts, presents, and futures.

Acknowledgements We are grateful to Teresa Gonzales and Gillian Gaultieri for their generous feedback on early drafts of this article. We also received generous feedback from the participants in "The Future of Sociology's History" meeting, from anonymous reviewers, and the editor.

\section{Declarations}

Conflict of Interest On behalf of all authors, the corresponding author states that there is no conflict of interest.

\section{References}

Abend, G. (2008). The meaning of 'Theory.' Sociological Theory, 26(2), 173-199.

Anderson, C. (2016). White rage: The Unspoken Truth of our Racial Divide. Bloomsbury Publishing USA.

Anderson, J. D. (1993). Race, meritocracy, and the American Academy during the Immediate Post-World War II Era. History of Education Quarterly, 33(2), 151-175.

Anderson, J. D. (2002). Race in American higher education: Historical perspectives on current conditions. In Racial Crisis in American Higher Education: Continuing Challenges for the Twenty-First Century edited by William A. Smith, Philip G. Altbach, and Kofi Lomotey. State University of New York Press.

Anzaldúa, G. (1999). Borderlands/la frontera: The New Mestiza. Aunt Lute Books.

Battle-Baptiste, W., \& Rusert, B. (2018). WEB Du Bois's Data Portraits: Visualizing black America. Chronicle Books.

Blomström, M., \& Hettne, B. (1984). Development Theory in Transition: The Dependency Debate \& Beyond: Third World Responses. Zed Books Ltd.

Bonilla-Silva, E. (2003). Racism without Racists: Color-Blind Racism and the Persistence of Racial Inequality in the United States. Rowman and Littlefield.

Bonus, R. (2020). The Ocean in the School: Pacific Islander Students Transforming their University. Duke University Press.

Bowen, W. G., \& Bok, D. (1998). The Shape of the River. Princeton University Press.

Breslau, D. (2007). The American Spencerians: Theorizing a new science. In Sociology in America: A History edited by Craig Calhoun. University of Chicago Press.

Brewer, R. M. (2005). Response to Michael Buroway's commentary: 'The critical turn to public sociology.' Critical Sociology, 31(3), 353-359.

Brodkin Sacks, K., \& Brodkin, K. (1998). How Jews Became White Folks and what that Says about Race in America. Rutgers University Press.

Brostelmann, T. (2001). The Cold War and the Colorline: American Race Relations in a Global Arena. Harvard University Press.

Brunsma, D. L., \& Wyse, J. P. (2019). The possessive investment in white sociology. Sociology of Race and Ethnicity, 5(1), 1-10. https://doi.org/10.1177/2332649218809968.

Buggs, S. G., Sims, J. P., \& Kramer, R. (2020). Rejecting white distraction: A critique of the white logic and white methods in academic publishing. Ethnic and Racial Studies, 43(8), 1384-1392.

Calhoun, C. (2007). "Preface" and "Sociology in America: An introduction." In Sociology in America: A History edited by Craig Calhoun. University of Chicago Press.

Calderon, D. (2014). Anticolonial methodologies in education: Embodying land and indigeneity in Chicana feminisms. Journal of Latino/Latin American Studies, 6(2), 81-96. 
Camic, C. (2007). On Edge: Sociology During the Great Depression and the New Deal. In Sociology in America: A History edited by Craig Calhoun. University of Chicago Press.

Connell, R. W. (1997). Why is classical theory classical? American Journal of Sociology, 102(6), 1511-1557.

Connell, R. (2007). Southern Theory: The Global Dynamics of Knowledge in Social Science. Polity.

Connell, R. (2019). Thoughts on social justice and universities. In Higher Education, Pedagogy and Social Justice (pp. 23-36). Springer.

Cooper, A. J. (2000). The Voice of Anna Julia Cooper: Including A Voice from the South and other Important Essays, Papers, and Letters. Rowman \& Littlefield Publishers.

Cooper, B. C. (2017). Beyond Respectability: The Intellectual Thought of Race Women. University of Illinois Press.

Crenshaw, K. (1990). Mapping the margins: Intersectionality, identity politics, and violence against women of color. Stanford Law Review., 43, 1241.

Cuatro, N. (2013). A sociological reading of classical sociological theory. Philippine Sociological Society, 61(2), 265-287.

Deegan, M. J. (1988). Jane Addams and the Men of the Chicago School, 1892-1918. Transaction Publishers.

Delmont, M. F. (2016). Why Busing Failed: Race, Media, and the National Resistance to School Desegregation. University of California Press.

Du Bois, W. E. B. (1935). Black Reconstruction. The Free Press.

Du Bois, W. E. B. (1940). Dusk of Dawn. Oxford University Press.

Du Bois, W. E. B., \& Edwards, B. H. (2008). The Souls of Black Folk. Oxford University Press.

Escobar, A. (2007). Worlds and knowledges otherwise: The latin American modernity/ coloniality research program. Cultural Studies, 21, 179-210.

Evans, S. Y. (2016). Black Women in the Ivory Tower, 1850-1954. University Press of Florida.

Fanon, F. (1963). The Wretched of the Earth. Grove Press.

Feagin, J. R. (2001). Social justice and sociology: Agendas for the twenty-first century: Presidential address. American Sociological Review, 66(1), 1-20. JSTOR. www.jstor.org/stable/2657391. Accessed 29 July 2020.

Ferguson, R. A. (2012). Reorder of Things: The University and its Pedagogies of Minority Difference. University of Minnesota Press.

Gonzales, T. I. (2020). Rachet and Rasquache: Aesthetic and discursive frames within Chicago-based women-of-color activism. Social Problems. https://doi.org/10.1093/socpro/spaa034.

Go, J. (2013a). For a postcolonial sociology. Theory and Society, 42, 25-55.

Go, J. (2013b). Sociology's imperial unconscious: The emergence of American sociology in the context of empire. In G. Steinmetz (Ed.), Sociology and Empire: The Imperial Entanglements of a Discipline. (pp. 83-105). Duke University Press.

Go, J. (2016). Postcolonial Thought and Social Theory. Oxford University Press.

Go, J. (2017). Decolonizing sociology: Epistemic inequality and sociological thought. Social Problems, 64, 194-199.

Go, J. (2020). Race, empire, and epistemic exclusion: Or the structures of sociological thought. Sociological Theory, 38(2), 79-100.

Grosfoguel, R, \& Cervantes-Rodríguez, A. M. (2002). Introduction: Unthinking Twentieth-Century Eurocentric Mythologies: Universalist Knowledges, Decolonization, and Developmentalism. Pp. xi-xxx in The Modern/ Colonial/ Capitalist World-System in the Twentieth Century: Global Processes, Antisystemic Movements, and Geopolitics of Knowledge, edited by R. Grosfoguel and A. M. Cervantes-Rodríguez.

Hill Collins, P. (2007). Pushing the boundaries or business as usual?: Race, class, and gender studies and sociological inquiry." In Sociology in America: A History edited by Craig Calhoun. University of Chicago Press.

Itzigsohn, J., \& Brown, K. L. (2020). The Sociology of W.E.B. Du Bois. New York University Press.

Jacobson, M. F. (1999). Whiteness of a Different Color. Harvard University Press.

James, C. L. R. (2001). The Black Jacobins: Toussaint L'Ouverture and the San Domingo Revolution. Penguin UK.

Jung, M.-K. (2009). The racial unconscious of assimilation theory. Du Bois Review, 6(2), 375-395.

Jung, M.-K. (2019). The enslaved, the worker, and Du Bois's black reconstruction: Toward an underdiscipline of antisociology. Sociology of Race and Ethnicity, 5(2), 157-168.

Krenn, M. L. (2006). The Color of Empire: Race and American Foreign Relations. Potomac Books Inc. 
Krenn, M. L. (2012). Token diplomacy: The United States, race, and the cold war. Pp. 3-32 in Race, Ethnicity, and the Cold War: A Global Perspective, edited by P. E. Muehlenbeck. Vanderbilt University Press.

Lengermann, P. M., \& Niebrugge, G. (2006). The women founders: Sociology and social theory 18301930, a Text/Reader. Waveland Press (Original work published in 1998).

Lengermann, P, \& Niebrugge, G. (2007). Thrice told: Narrative of sociology's relation to social work. In Sociology in America: A History edited by Craig Calhoun. University of Chicago Press.

Magubane, Z. (2016). American sociology's racial ontology: Remembering slavery, deconstructing modernity, and charting the future of global historical sociology. Cultural Sociology, 10(3), 369-384.

Matthew, P. A. (2016). Written/Unwritten: Diversity and the Hidden Truths of Tenure. University of North Carolina Press.

Mignolo, W. D. (2002). The geopolitics of knowledge and the colonial difference. South Atlantic Quarterly, 101(1), 57-96.

Mignolo, W. D. (2005). The Idea of Latin America. Blackwell Publishing.

Mills, C. W. (1959). The Sociological Imagination. Oxford University Press.

Molina, N. (2014). How Race Is Made in America: Immigration, Citizenship, and the Historical Power of Racial Scripts. (Vol. 38). University of California Press.

Morris, A. D. (2007). Sociology of race and W.E.B. DuBois. In Sociology in America: A History edited by Craig Calhoun. University of Chicago Press.

Morris, A. D. (2015). The Scholar Denied: W.E.B. Du Bois and the Birth of Modern Sociology. University of California Press.

Okechukwu, A. (2019). To Fulfill These Rights: Political Struggle over Affirmative Action and Open Admissions. Columbia University Press.

Okihiro, G. Y. (2016). Third world studies: Theorizing liberation. Duke University Press.

Omi, M., \& Winant, H. (1994). Racial Formation in the United States: From the 1960s to the 1990s (Critical Social Thought). Routledge.

Parsons, T. (1937). The Structure of Social Action: A Study in Social Theory with Special Reference to a Group of Recent European Writers. The Free Press.

Pérez Huber, L., Vélez, V. N., \& Solórzano, D. (2018). More than 'Papelitos:' A quantcritcounterstory to critique latina/o degree value and occupational prestige. Race Ethnicity and Education, 21(2), 208-230.

Perkins, L. M. (2018). The black female professoriate at Howard University: 1926-1977. In Women's Higher Education in the United States edited by Margaret A. Nash. Palgrave Macmillan.

Peters, B. J. (1991). Disparate voices: The magic show of sociology. The American Sociologist, 22(3/4), 246-260.

Prashad, V. (2007). The Darker Nations: A People's History of the Third World. The New Press.

Quijano, A. (2007). Coloniality and modernity/rationality. Cultural Studies, 21, 168-178.

Quijano, A., \& Wallerstein, I. (1992). Americanity as a concept of the americas in the modern worldsystem. International Social Science Journal, 44, 549-557.

Rivera Cusicanqui, S. (2012). Violencias (re)encubiertasen Bolivia. Editorial Otramérica.

Robinson, C. (2005). Black Marxism: The Making of the Black Radical Tradition. University of North Carolina Press.

Robinson, C. (2007). Forgeries of Memory and Meaning: Blacks and the Regimes of Race in American Theater and Film before World War II. University of North Carolina Press.

Romero, M. (2020). Sociology engaged in social justice. American Sociological Review, 85(1), 1-30. https://doi.org/10.1177/0003122419893677.

Sandoval, C. (2013). Methodology of the Oppressed. University of Minnesota Press.

Simpson, A. (2014). Mohawk interruptus: Political Life Across the Borders of Settler States. Duke University Press.

Sims, J. P., Pirtle, W. L., \& Johnson-Arnold, I. (2019). Doing hair, doing race: The influence of hairstyle on racial perception across the U.S. Ethnic and Racial Studies, 43(12), 2099-2119.

Small, A. W. (1912). General sociology. American Journal of Sociology, 18(2), 200-214.

Smith, C. M. (2016). Reparation and Reconciliation: The Rise and Fall of Integrated Higher Education. University of North Carolina Press.

So, A. Y. (1990). Social Change and Development: Modernization, Dependency and World-System Theories. Sage Publications. 
Steinmetz, G. (2013). Major Contributions to Sociological Theory and Research on Empire. In G. Steinmetz (Ed.), Sociology and Empire: The Imperial Entanglements of a Discipline. (pp. 1-50). Duke University Press.

Trouillot, M.-R. (1995). Silencing the Past: Power and the Production of History. Beacon Press.

Tuck, E., \& Yang, K. W. (2012). Decolonization is not a metaphor. Decolonization: Indigeneity, Education \& Society, 1(1), 1-40.

Vitalis, R. (2015). White World Order, Black Politics: The Birth of American International Relations. Cornell University Press.

Wells-Barnett, I. B. (2012). The Red Record Tabulated Statistics and Alleged Causes of Lynching in the United States. Tredition.

Williams, A. J. (2018). Who teaches academics to theorize? Conditionally Accepted. https://www.insid ehighered.com/advice/2018/06/15/theorizing-black-scholars-differs-white-western-academic-stand ards-no-less-valid. Accessed 29 July 2020.

Winant, H. (2007). The dark side of the force: One hundred years of the sociology of race." In Sociology in America: A History edited by Craig Calhoun. University of Chicago Press.

Wright, E., II. (2002a). Using the master's tools: The Atlanta sociological laboratory and American sociology, 1896-1924. Sociological Spectrum, 22(1), 15-39.

Wright, E., II. (2002b). The Atlanta sociological laboratory 1896-1924: A historical account of the first american school of sociology. Western Journal of Black Studies, 26(3), 165-174.

Wright, E., II. (2012). The First American School of Sociology: W.E.B. Du Bois and the Atlanta Sociological Laboratory. Routledge.

Yu, H. (2001). Thinking Orientals: Migration, Contact, and Exoticism in Modern America. Oxford University Press.

Zuberi, T., \& Bonilla-Silva, E. (2008). White Logic, White Methods: Racism and Methodology. Rowman \& Littlefield Publishers.

Publisher's Note Springer Nature remains neutral with regard to jurisdictional claims in published maps and institutional affiliations. 